\title{
Studies on Trypsin Covalently Bound to RNA
}

\author{
Yozo TAKASAKI \\ Department of Biochemistry, Kyushu University School of Medicine, Fukuoka 812 \\ Received October 24, 1977
}

\begin{abstract}
Bovine trypsin (EC 3.4.4.4) was bound to RNA in the presence of water-soluble carbodiimide [1-ethyl-3-(3-dimethylaminopropyl)-carbodiimide], and the enzymic properties of this complex were compared with those of free trypsin. RNA bound trypsin does not lose its activity in the presence of $0.5 \% \mathrm{SDS}$, and this is consistent with the fact that the intensity of the fluorescence spectrum of this complex does not change when SDS is added. The RNAenzyme complex seems suitable for studies on the conformation of immobilized enzyme.
\end{abstract}

There have been many reports on immobilized enzymes, but little is yet known about the chemical and physicochemical properties of these enzymes. Here we define immobilized enzymes as enzymes bound to carriers, even when the resulting complexes are soluble. Therefore we studied the physicochemical characters of immobilized trypsin using yeast RNA as a soluble carrier. RNA is a suitable carrier because the amino groups in its adenine and cytosine bases are easily bound to carboxyl groups of enzymes in the presence of watersoluble carbodiimide. Another advantage is that RNA shows no emission peaks near those of the aromatic amino acid residues of trypsin at $330 \mathrm{~nm}$, so fluorescence studies on trypsin bound to RNA can be carried out. This paper reports the enzymic properties of the RNAtrypsin complex and the availability of this type of complex for studies on the conformation of immobilized enzyme.

\section{MATERIALS AND METHODS}

Bovine trypsin (type III, $2 \times$ crystallized) and $\alpha$ casein were purchased from Sigma Chemical Co., yeast RNA was from Kohjin Co., Ltd., water-soluble carbodiimide was from the Protein Research Foundation, Osaka, and benzoyl-D,L-arginyl-p-nitroanilide (BAPA) from Fluka AG, Buchs SG, Switzerland.

Fluorescence spectra were examined in a Hitachi Fluorescence Spectrophotometer MPF-4.

RNA was deproteinized by the method of Kirby ${ }^{1)}$ before coupling with trypsin. The RNA-trypsin complex was synthesized as follows; $0.1 \mathrm{~g}$ of RNA and $25 \mathrm{mg}$ of trypsin were suspended in $5 \mathrm{ml}$ of $0.02 \mathrm{M}$
$\mathrm{KCl}-\mathrm{HCl}$ buffer ( $\mathrm{pH} \mathrm{2.2)}$. Then $0.05 \mathrm{ml}$ of watersoluble carbodiimide was added with stirring at $0^{\circ} \mathrm{C}$ for $30 \mathrm{hr}$, and the mixture was applied to a CM-cellulose column equilibrated with $0.05 \mathrm{M}$ acetate- $\mathrm{HCl}$ buffer (pH 3.0) to separate the RNA-trypsin.

The phosphorus content of RNA was determined by the method of Lowry et al. ${ }^{2}$.

\section{RESULTS AND DISCUSSION}

The elution profile on CM-cellulose column chromatography is shown in Fig. 1. Peak 1 in Fig. 1 is attributable to RNA and water-soluble carbodiimide, and peak 2 to RNA-trypsin, because it has BAPA hydrolyzing activity and contains phosphorus. Free trypsin was obtained in peak 3 by elution with a $0.1 \sim 0.3 \mathrm{M}$ $\mathrm{NaCl}$ gradient. It was calculated that one molecule trypsin was bound per 31 nucleotides of RNA (Table I).

Table I summarizes some of the properties of trypsin bound to RNA with those of free trypsin for comparison. Free trypsin was prepared at the same time as the trypsin used for synthesis of the RNA-trypsin complex, and hereafter "free trypsin" refers this enzyme: that is, trypsin under the same conditions as the RNA-trypsin complex. The BAPA hydrolyzing activity of RNA bound trypsin was almost the same as that of free trypsin, but the caseinolytic activity and $K m$ value for BAPA at $\mathrm{pH} 8.1$ were different from those of free trypsin. This difference seems reasonable because the microenvironments of the enzymes were different. 


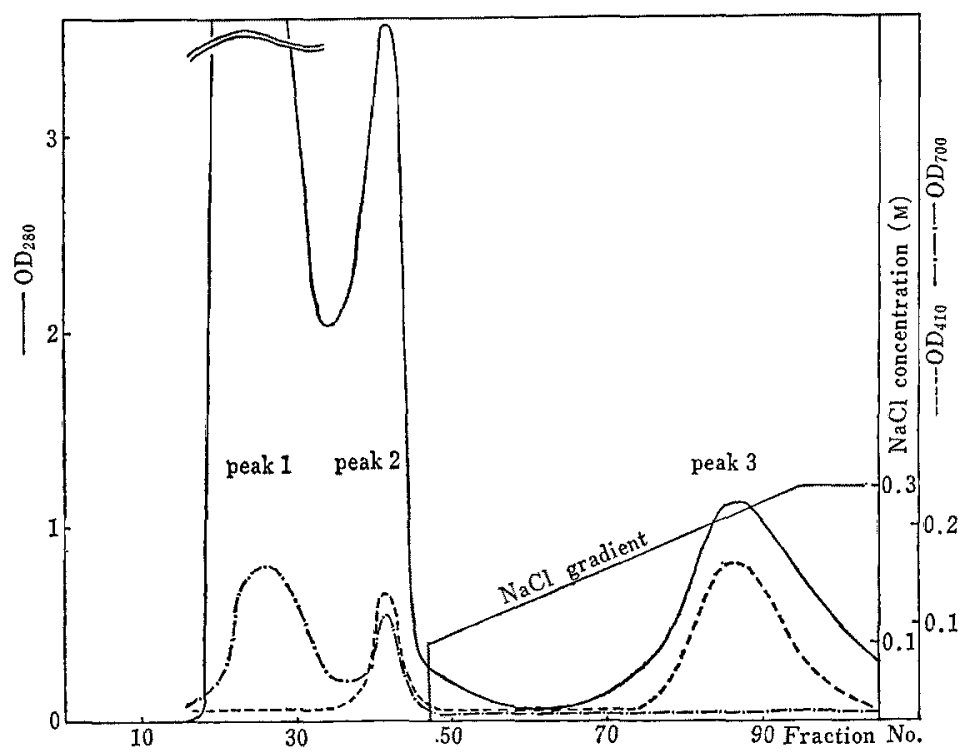

FIG. 1. Separation of the RNA-trypsin Complex by CM-cellulose Column Chromatography (column size $2 \mathrm{~cm} \times 35 \mathrm{~cm}$ ).

Fractions of $3 \mathrm{ml}$ were collected. An $\mathrm{NaCl}$ gradient was applied from fraction No. 47 .

- absorbance at $280 \mathrm{~nm} ; \cdots \cdots$, BAPA hydrolyzing activity, measured as absorbance at 410 $\mathrm{nm}$; -.---, phosphorus content, measured as absorbance at $700 \mathrm{~nm}$.

Table I. Comparison of Enzymic Properties OF RNA-TRYPSIN AND FREE TRYPSIN

BAPA hydrolyzing and caseinolytic activities were measured at $\mathrm{pH} 8.1$ and $37^{\circ} \mathrm{C}$ on reaction for $10 \mathrm{~min}$ and the reactions with BAPA and casein were stopped by adding $10 \%$ acetic acid and $7 \%$ trichloroacetic acid, respectively.

\begin{tabular}{|c|c|c|c|c|}
\hline & $\begin{array}{c}\text { Specific } \\
\text { activity } \\
\text { (substrate: } \\
\text { BAPA) }\end{array}$ & $\begin{array}{c}\text { Specific } \\
\text { activity }^{a} \\
\text { (substrate: } \\
\alpha \text {-casein) }\end{array}$ & $\begin{array}{c}K m \text { for } \\
\text { BAPA } \\
\text { at pH 8.1 } \\
(\mathrm{mM})\end{array}$ & $\begin{array}{l}\text { Phos- } \\
\text { phorus } \\
\text { per } \\
\text { trypsin }\end{array}$ \\
\hline \multicolumn{4}{|l|}{ RNA- } & 31.2 \\
\hline \multicolumn{4}{|l|}{ Free } & 0.0 \\
\hline a The & $\begin{array}{l}\text { ntration w } \\
\text { et al. }\end{array}$ & on were & alculated & $\begin{array}{l}\text { king the } \\
\text { Proteir } \\
\text { ethod o }\end{array}$ \\
\hline
\end{tabular}

The optimum $\mathrm{pH}$ for activity of RNAtrypsin toward BAPA was 8.1 , which is the same as that of free trypsin.

The heat stability of RNA-trypsin was also apparently the same as that of free trypsin, as shown in Table II, but its resistance to the denaturant SDS was different from that of free
Table II. Comparison of the Heat Stabilities OF RNA-TRYPSIN AND FREE TRYPSIN

Samples were preincubated at $\mathrm{pH} 3.0$ for $10 \mathrm{~min}$ at each temperature, and then incubated with $2 \mathrm{~mm}$ BAPA at $\mathrm{pH} 8.1$ and $37^{\circ} \mathrm{C}$ for $10 \mathrm{~min}$. The values listed here were determined taking the activities of both enzymes at $37^{\circ} \mathrm{C}$ as 100 . Samples containing $40 \mu \mathrm{g}$ protein were used.

\begin{tabular}{lcc}
\hline & $\begin{array}{c}\text { Preincubation } \\
\text { temperature }\end{array}$ & $\begin{array}{c}\text { BAPA hydrolyzing } \\
\text { activity }\end{array}$ \\
\hline RNA-trypsin & $37^{\circ} \mathrm{C}$ & 100 \\
& $60^{\circ} \mathrm{C}$ & 98 \\
Free trypsin & $80^{\circ} \mathrm{C}$ & 70 \\
& $37^{\circ} \mathrm{C}$ & 100 \\
& $60^{\circ} \mathrm{C}$ & 87 \\
& $80^{\circ} \mathrm{C}$ & 70 \\
\hline
\end{tabular}

trypsin as shown in Fig. 2. The fact that trypsin bound to RNA is resistant to $1 \%$ SDS, suggests that its conformation does not change on addition of SDS. This possibility was supported by the results of fluorescence spectroscopy shown in Fig. 3: addition of 1\% SDS did not change or slightly increased the fluorescence intensity of RNA-trypsin around 330 $\mathrm{nm}$ due to tryptophan or tyrosine, whereas it 


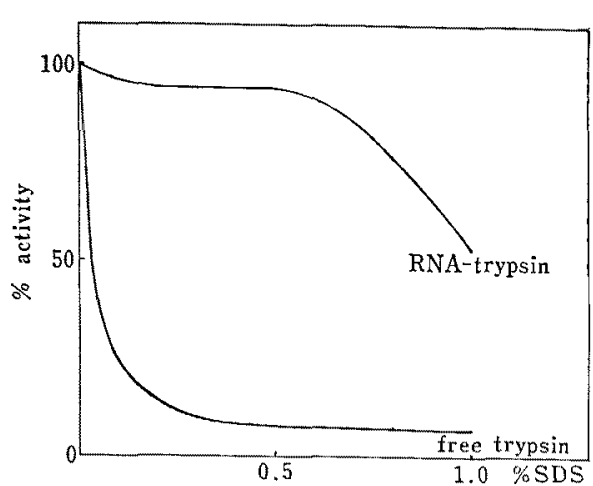

Frg. 2. Resistance of BAPA Hydrolyzing Activity of RNA-trypsin to SDS.

Experimental conditions were as for Table I.

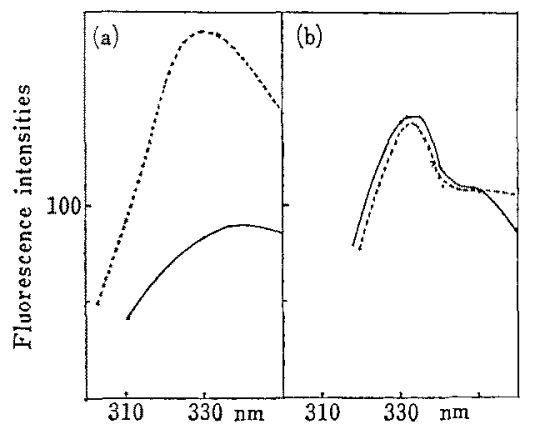

FIG. 3. Fluorescence Emission Spectra of RNAtrypsin and Free Trypsin.

(a) free trypsin, excited at $289 \mathrm{~nm}$, (b) RNA-trypsin, excited at $291 \mathrm{~nm} . \quad \cdots \cdots$, at $\mathrm{pH} 8.1$; —, at $\mathrm{pH} 8.1$ plus $1 \%$ SDS. Fluorescence, calculated for a fixed protein concentration, is shown in arbitrary units.

greatly decreased that of free trypsin. The reasons for these interesting phenomena are unknown.

Katchalsky et al. ${ }^{4)}$ reported similar results on trypsin bound to Sephadex in the presence of $8 \mathrm{M}$ urea. Further studies are required to elucidate these phenomena.
The transfer RNA-aminoacyl tRNA synthetase complex which was synthesized photochemically by Schimmel et $a l^{5,6}$ is useful for obtaining information on the specific nucleotides of tRNA that interact with the specific aminoacyl tRNA synthetase. Our RNAtrypsin complex synthesized in the presence of water-soluble carbodiimide is also useful for investigating the interaction of amino acid residues of the enzyme with carriers. However, we failed to identify the main amino acid residues of trypsin that are covalently bound to RNA: under our conditions the carboxyl groups of trypsin seem to bind amino groups of RNA in a random manner during reaction for $30 \mathrm{hr}$ (data not shown).

It is true RNA is not suitable for studies on the conformation of immobilized enzyme because it has a strong absorption peak around $260 \mathrm{~nm}$, but fluorescence studies should provide information on the structure of the immobilized enzyme and therefore be helpful in improving the method for enzyme-immobilization.

Acknowledgement. We thank Prof. T. Ohta (Tokyo University) for valuable advice and discussion.

\section{REFERENCES}

1) K. S. Kirby, Biochem. J., 64, 405 (1956).

2) O. Lowry, N. R. Roberts, K. Y. Leiner, M. L. Wu and L. Farr, J. Biol. Chem., 207, 1 (1954).

3) O. H. Lowry, N. J. Rosenbrough, A. J. Farr and R. J. Randall, ibid., 193, 265 (1951).

4) D. Gabel, I. Z. Steinberg and E. Katchalsky, Biochemistry, 10, 4661 (1971).

5) G. P. Budzik, S. S. M. Lam, H. J. P. Schoemaker and P. R. Schimmel, J. Biol. Chem., 250, 4433 (1975).

6) H. J. P. Schoemaker, G. P. Budzik, R. Giegé and P. R. Schimmel, ibid., 250, 4440 (1975). 